SVU- International Journal of Veterinary Sciences, 4 (3): 1-11, 2021.

Print ISSN: 2535-1826

\title{
Hygienic and Sanitary Condition of Environment and Meat Surfaces in the Restaurant of Sohag University Hospital
}

\section{Abeera Mahmoud El-Sayed", Motamed Elsyed Mahmoud*2, Sotohy Ahmed Mohamed ${ }^{* 3}$}

${ }^{1}$ Fellow- Sohag University Hospital, Sohag University, Sohag, 82524, Egypt, ${ }^{2}$ Department of Animal Behavior and Husbandry (Genetics, Breeding and Production), Faculty of Veterinary Medicine, Sohag University, Sohag, 82524, Egypt, ${ }^{3}$ Department of Animal and Environmental Hygiene, Faculty of Veterinary Medicine, Assiut University, 71526, Egypt.

\section{Abstract}

The microbiological quality of red meat produced from most of the food-processing plants in Egypt has always been questionable. This study aimed to examine the bacteriological quality of a restaurant in the Sohag University hospital environment (air, water; worker's hands, worker's clothes, and knives) beside the meat surfaces. Bacteriological examination was performed for air, water, worker's hands, worker's clothes, and knives, in addition to the meat surfaces. Mean total bacterial count; TBC, total coliform count; TCC, total fecal coliform count; TFCC, total Escherichia coli count, and total Staphylococcus aureus were carried out. The obtained results revealed that the TBC, TCC, TFCC, and total E. coli counts were higher than the recommended standard for sanitary practices. In addition, we observed that worker's clothes contain more bacterial count than the hands and knives. The knives' swabs contained less bacterial burden but still higher than the recommended guidelines. In addition, 9 bacterial isolates were consistently isolated during this study including; E. coli, Staphylococcus aureus, Staphylococcus epidermidis, Pseudomonas aeroginosa, Enterobacter spp, Klebsiella spp., Proteus spp, Citrobacter spp, and Serratia spp. with varying percentages of frequency across the sampling points. Whereas, none of Salmonella spp. were isolated. In conclusion, the presence of pathogenic microorganisms in this study is of special concern and meat hygienists should be fortified to review the processes involved in the environment surrounding the meat as well as meat processing of university restaurants in Egypt.

Keywords:

Bacteriological Examination, Restaurant Environment, Meat Surface Contamination.

DOI: 10.21608/svu.2021.65185.1116 Received: March 21, 2021 Accepted: June 23, 2021 Published: July 04, 2021 *Corresponding Authors: Sotohy Mohamed E-mail: sotohy2000@yahoo.com and Motamed Elsayed Mahmoud_E-mail: motamed71111@gmail.com Citation: El-Sayed et al., Hygienic and Sanitary Condition of Environment and Meat Surfaces in the Restaurant of Sohag University Hospital. SVU-IJVS 2021, 4 (3): 1-11.

Copyright: (C) El-Sayed et al. This is an open access article distributed under the terms of the creative common attribution license, which permits unrestricted use, distribution and reproduction in any medium provided the original author and source are created.

Competing interest: The authors have declared that no competing interest exists. 


\section{Introduction}

The hygienic state of the University hospital restaurant in Sohag was evaluated from the bacteriological point of view. The continuous drive to increase the hygiene standards carries many challenges for meat hygienists especially in developing countries (Adesokan and Raji, 2014). Preventing foodborne illnesses remains a major public health concern. All over the world, millions of people get sick from the food they eat (world health organization; WHO, 2015). Unsafe food harboring pathogens causes over 200 diseases in the world (WHO, 2020). Most of these illnesses can be prevented. The restaurant's environment is including air, walls, floors, workers' hands and clothes, contact surfaces, water, soils, and used instruments. These environments may represent the main sources of meat contamination (McLaughlin and Mineau, 1995; Sinha, 1997; Bridges et al., 2000; Boadi and Kuitunen, 2003; Amisu et al., 2003; and CDC, 2019). Pathogenic microorganisms detected in animal carcasses or shed in animal wastes may be a considerable source of hazards with many pathogens including Salmonella, Escherichia coli 0157:H7, Yersinia enterocolitica, Campylobacter, Cryptosporidium parvum, and Giardia lamblia (Ferragut et al., 2015).

Meat and meat by products were contaminated by microorganisms including airborne bacteria and molds is a major commercial problem in meat manufacturing (Rawat, 2015). Unhygienic environmental conditions in food processing plants can arise due to suspended particles in the air (Oliveira et al., 2020). These particles are microscopic, carrying microbes, and are suspended in the air as an aerosol (Fernandez et al., 2019). Airborne impurities are considered biological and known as bio-aerosols, and include bacteria, viruses, fungi, and pollen grains (Lou et al., 2021). These particles are existing in the air as solid (dust) or as a liquid. Some time ago it was thought that food products get contaminated when they encountered unclean surfaces but now it is known that additional product contamination arises from contact with airborne pathogens (Kornacki, 2014; and Bintsis, 2017). Tap water used for cleaning, and washing may be a significant source of contaminating meat and its products (WHO, 1970; Hegazi, 1995; and Milios et al., 2014). Moreover, meat contact surfaces as worker's hands, worker's clothes, and knives used in the food processing areas carry many pathogens, which transferred directly to meat (Chan and Mowad 1998; Smith, 2000; and Levin and Warshaw, 2008). Therefore, meat processing plants should equip workers with the correct kinds of utensils and basic equipment. Such utensils and tools must be subjected to simple routine examination and maintenance to be carried out by the persons in charge on a regular basis (Schmidt, 2019). This does not include the checking of more sophisticated equipment, which must be undertaken by specialized technicians usually obtained from the supplier companies.

Several species of pathogenic bacteria and fungi have been isolated from foodprocessing plant's environments such as Staphylococcus, E. coli, Streptococcus, Salmonella, Aspergillus, Mucor, Saccharomyces and Penicillium species (Amisu et al., 20003). These pathogens might threaten public health by contaminating the meat (Meadows, 1995, Gauri, 2004, Raheem and Morenikeji, 2008). Pathogenic airborne and spoilage microorganisms can be presented to meat in several pathways. It is known that contamination can occur at several points during transportation from the abattoir, processing, and storage.

Although coliforms were easy to detect, their association with fecal contamination was questionable because some coliforms are found naturally in environmental samples (Caplenas et al., 1984). This led to the introduction of the 
fecal coliforms as an indicator of contamination. Fecal coliform, first defined based on the works of Eijkman (Eijkman, 1904) is a subset of total coliforms that grows and ferments lactose at elevated incubation temperature, hence also referred to as thermo-tolerant coliforms. Fecal coliform analyses are done at $45.5^{\circ} \mathrm{C}$ for food testing, except for water, which use $44.5^{\circ} \mathrm{C}$ (Neufeld, 1984; and American Public Health Association (APHA), 1998). The Most Probable Number (MPN) method is a statistical, multi-step assay consisting of presumptive, confirmed and completed phases. Feng et al., (1995) indicated that presence of $E$. coli in food or water became accepted as indicative of recent fecal contamination and the possible presence of some other pathogens as Citrobacter, Klebsiella and Enterobacter that can also ferment lactose and are similar to $E$. coli in phenotypic characteristics, so that they are not easily distinguished. The term "coliform" was coined to describe this group of enteric bacteria. Coliform is not a taxonomic classification but rather a working definition used to describe a group of Gram-negative, facultative anaerobic rod-shaped bacteria that ferments lactose to produce acid and gas within $48 \mathrm{~h}$ at $35^{\circ} \mathrm{C}$. In 1914, the U.S. Public Health Service adopted the enumeration of coliforms as a more convenient standard of sanitary significance.

Consequently, this work was performed to investigate the degree of bacterial contamination of environmental components of the restaurant of Sohag University Hospital and meat surface.

\section{Materials and methods}

\section{Sampling:}

The environmental samples were collected from the restaurant of Sohag University Hospital. Twenty-eight samples were collected from each item including air, water, worker's hands, worker's clothes, and knives, beside the meat surfaces as described below:

1.1. Workers' hands, clothes, and knives: Twenty-eight swabs were collected from the hands' palms, fingers and nails, $20 \mathrm{~cm}^{2}$ template was used to mark the area of sampling. Pre-moistened swabs with peptone water $0.1 \%$ were used to swab the marked area (AOAC Official Mehthods of Analysis, 2019). The collected swabs were dipped in sterile screw-capped bottles containing $10 \mathrm{ml}$ peptone water $0.1 \%$ (Vuia-Riser et al., 2018).

1.2. Air: Twenty-eight air samples were collected using liquid impinger (Sigma Aldrich, USA) at the mid-day during working hours (Santl-Temkiv et al., 2017). Sterile phosphate-buffered saline $(25 \mathrm{ml})$ was used for the collection of suspended dust particles. The liquid impinger was adjusted at a rate of $5 \mathrm{~L} / \mathrm{min}$. During sampling, the liquid impinge was moved all around the processing area of the restaurant to trap the finely suspended dust particles. The suspension in the liquid impinger was thoroughly shaken in order to obtain a homogenous distribution of its bacterial content.

1.3. Water samples: A total of 28 water samples of tap water used in food processing were collected in sterile transparent $500 \mathrm{ml}$ capacity glass bottles (WHO, 2006). The bottles were fitted with sterile ground glass stoppers.

All samples were sent to the laboratory in an icebox within the minimum delay for further bacteriological examination.

\section{Bacteriological Examination}

2.1. Total colony count (TCC), total fecal coliform count (TFCC), total E. coli count, and total Staph. aureus counts were performed. Isolation and identification of pathogenic bacteria were conducted according to previous methods (Cruickshank et al., 1980; American Public 
Health Association (APHA), 2005; Paul and Janet, 2008; WHO, 2010; and AOAC, 2019).

2.2. Plate count method was used to enumerate the presence of aerobic plate count, coliform, E. coli and S. aureus (Cruickshank et al., 1980). Plate count agar (PCA; Merck, Germany), violet red bile dextrose agar (VRBD; Merck, Germany) and eosin methylene blue agar (EMB; Merck, Germany), and Mannitol salt agar (HiMedia Laboratories, LLC, India) were used respectively. Ten-fold serial dilutions were conducted on the thoroughly homogenized samples. Plating $0.1 \mathrm{~mL}$ aliquot from each dilution on the specified media. The plates were then incubated aerobically at $37^{\circ} \mathrm{C}$ for $24 \mathrm{~h}$. The countable plates were selected where the colonies were counted and recorded.

2.3. Ten tube Most Probable Number (MPN) coliform test - Presumptive and Confirmed procedures. The MPN method confirmed and completed phases. In the assay, serial dilutions of a sample were inoculated into broth media. Analysts scored the number of positive tubes (acid and gas) as indication of lactose fermentation. With $10 \mathrm{~mL}$ of undiluted of each were inoculated into 10 tubes of $2 \mathrm{x}$ Lauryl tryptose (LST) broth $(10 \mathrm{~mL}$ of medium). Incubate tubes at $35^{\circ} \mathrm{C}$. Then tubes were examined at $24 \pm 2 \mathrm{~h}$ for growth and gas formation. If they were negative at $24 \mathrm{~h}$, re-incubated for an additional $24 \mathrm{~h}$ and examined again for gas. Perform a confirmed test on all presumptive positive (gassing) tubes as follow:

2.4. MPN - Confirmed test for coliforms: From each gassing LST or lactose broth tube, transfer a loopful of suspension to a tube of BGLB broth. Incubate BGLB tubes at $35^{\circ} \mathrm{C} \pm 0.5^{\circ} \mathrm{C}$ and examine for gas production at $48 \pm 3 \mathrm{~h}$. and record. Calculate MPN using 10 tube MPN Table, Standard Methods for the Examination of Water and Wastewater (American Public Health Association. 1998).
2.5. MPN - Confirmed test for fecal coliforms and E. coli: From each gassing LST or Lactose broth tube from the Presumptive test, a loopful of each suspension were transferred to a tube of EC broth, incubate for $24 \pm 2 \mathrm{~h}$ at $44.5^{\circ} \mathrm{C}$ and examined for gas production. If negative, re-incubated and examined again at $48 \pm 2$ h. The results of this test were used to calculate fecal coliform MPN.

2.6. MPN - Completed test for E. coli: each gassing EC tube was gently agitated. A loopful of broth was streak on Levine's eosin-methylene blue (L-EMB) agar and incubated for $18-24 \mathrm{~h}$ at $35^{\circ} \mathrm{C} \pm 0.5^{\circ} \mathrm{C}$. Examine plates for suspicious $E$. coli colonies (dark centered and flat, with metallic sheen. Transfer up to 5 suspicious colonies from each L-EMB plate to Plate count agar (PCA) slants, incubate them for $18-24 \mathrm{~h}$ at $35^{\circ} \mathrm{C} \pm 0.5^{\circ} \mathrm{C}$ and use for further testing.

2.7. Bacterial colonies were further identified based on Bergey's Manual of Determinative Bacteriology (Williams, 2000) and Gram staining, Mannitol fermentation, hemolytic activities. Presumptive E. coli colonies detected on EMB agar were then subjected to standard biochemical tests (indole, methyl red, Voges-Proskauer, and citrate tests, urease, oxidase, and growth on triple sugar iron agar (da Silva et al., 2013).

\section{Statistical analyses}

Statistical analyses were conducted by GraphPad prism software (Version: 8.0.1.244). Correlation analyses for environmental variables (air, tap water, worker's hand clothing, and knives' swab) set against raw meat surface were performed by using Pearson's correlation. Correlation coefficient $[\mathrm{r}]$ is significant at $P$ $<0.05$. 


\section{Results and Discussion}

The production of food with high quality and safe for human consumption is the main target for all meat hygienists. Unfortunately, the bacteriological load of meat, air, and tap water used in the foodprocessing plants was higher than the recommended standard for sanitary practices. The mean total bacterial count of exposed meat surface was $4.5 \times 105$ CFU/cm2 (Table 1). This bacterial burden is higher than those previously recorded (Lee and Fung, 1986; and Fliss et al., 1991). The high bacterial count could be due to many reasons such as the bad handling of carcasses during evisceration and meat transportation from the abattoirs to the consumers (Roberts, 1980; and Gauri, 2004). Concerning the total colony count in air and tap water, results revealed that the mean count was $8.4 \times 103$ and $8.2 \times 102$, respectively (Table 1). These results indicate that both air and water may be considered vehicles for meat contamination (Raheem and Morenikeji, 2008). The bacterial isolates from air samples were Staph. epidermidis (27.3\%), Staph aureus (24.2\%), Klebsiella species (12.1\%), Citrobacter spp. (9.1\%), and Serratia spp. (9.1\%). E. coli was representing $6.2 \%$ of the isolates. A contamination of beef products processed in abattoirs could be contributed to various factors especially during processing and manipulations procedures such as skinning, evisceration, storage, and distribution at slaughterhouses and retail establishments (Doxon et al., 1991; and Milios et al., 2014). The food-processing hall's air may become major sources of meat contamination by these pathogenic and potentially pathogenic bacteria (Bintsis, 2017). Fortunately, in this study, most of the bacterial colonies isolated from the meat surfaces were non-pathogenic.

Table 1. The logarithm 10 of mean total bacterial, coliforms, fecal coliforms, E. coli and staph. aureus counts for samples collected from raw meat surface, air, water, worker's hands, clothes, and knives in the restaurant of Sohag University Hospital.

\begin{tabular}{|c|c|c|c|c|c|c|}
\hline Sample & Range & TBC & $\begin{array}{c}\text { TCC } \\
(\mathrm{MPN})\end{array}$ & $\begin{array}{l}\text { TFCC } \\
\text { (MPN) }\end{array}$ & $\begin{array}{l}\text { Total } E \text {. coli i. } \\
\text { count (MPN) }\end{array}$ & $\begin{array}{c}\text { Total Staph. } \\
\text { aureus }\end{array}$ \\
\hline \multirow{3}{*}{$\begin{array}{l}\text { Meat surface } \\
\left(\mathrm{CFU} / \mathrm{cm}^{2}\right)\end{array}$} & Minimum & 2.84 & 1.08 & 0.00 & 0.00 & 1.58 \\
\hline & Maximum & 9.38 & 4.46 & 2.79 & 1.91 & 3.83 \\
\hline & Mean & 5.65 & 2.46 & 2.16 & 1.00 & 2.41 \\
\hline \multirow{3}{*}{$\begin{array}{l}\text { Air } \\
\left(\mathrm{CFU} / \mathrm{m}^{2}\right)\end{array}$} & Minimum & 2.47 & 0.48 & 0.00 & 0.48 & 2.12 \\
\hline & Maximum & 5.72 & 3.18 & 2.42 & 2.00 & 3.32 \\
\hline & Mean & 3.92 & 2.31 & 2.09 & 1.48 & 2.71 \\
\hline \multirow{3}{*}{$\begin{array}{l}\text { Tap water } \\
\left(\mathrm{CFU} / \mathrm{m}^{2}\right)\end{array}$} & Minimum & 5.45 & 3.47 & 3.48 & 3.47 & 4.62 \\
\hline & Maximum & 7.41 & 3.46 & 3.45 & 3.46 & 6.58 \\
\hline & Mean & 5.91 & 3.46 & 3.45 & 3.47 & 4.76 \\
\hline \multirow{3}{*}{$\begin{array}{l}\text { Worker's } \\
\text { hands } \\
\left(\mathrm{CFU} / \mathrm{cm}^{2}\right)\end{array}$} & Minimum & 1.83 & 0.48 & 0.48 & 0.48 & 1.86 \\
\hline & Maximum & 2.71 & 2.55 & 1.80 & 1.15 & 2.36 \\
\hline & Mean & 1.89 & 1.68 & 1.45 & 0.90 & 2.38 \\
\hline \multirow{3}{*}{$\begin{array}{l}\text { Worker's } \\
\text { clothes } \\
\left(\mathrm{CFU} / \mathrm{cm}^{2}\right)\end{array}$} & Minimum & 1.99 & 0.48 & 0.48 & 0.48 & 1.73 \\
\hline & Maximum & 4.49 & 2.99 & 1.93 & 1.34 & 3.42 \\
\hline & Mean & 2.45 & 2.08 & 1.42 & 1.26 & 2.53 \\
\hline \multirow{3}{*}{$\begin{array}{l}\text { knives' } \\
\left(\mathrm{CFU} / \mathrm{cm}^{2}\right)\end{array}$} & Minimum & 1.36 & 0.00 & 0.48 & 0.00 & 1.58 \\
\hline & Maximum & 4.79 & 2.63 & 1.95 & 1.43 & 3.25 \\
\hline & Mean & 2.52 & 1.49 & 1.11 & 1.00 & 2.51 \\
\hline
\end{tabular}

TBC; total bacterial count, TCC; total coliform count, TFCC; total fecal coliform count, total E. coli count; MPN; most probable number, CFU; colony-forming unit. *Permissible limits of TBC for fresh meat $\left(10^{6}\right)$ according to the Egyptian Organization for Standardization and Quality (2005). *Permissible limits of Enterobacteriaceae and staphylococci $\left(10^{2}\right)$ according to Egyptian Organization for Standardization and Quality (2005). 
The mean total bacterial count (TBC), total colony count (TCC), total fecal coliform count (TFCC), total thermotolerant $E$. coli count (T. E. coli count) and T. Staph. aureus in the worker's hands $/ \mathrm{m} 2$ were $7.8 \times 10,4.8 \times 10,2.8 \times 10$, $0.8 \times 10$ and $2.4 \times 102$, respectively. Moreover, the mean TBC, TCC, TFCC, T. E. coli count, and T. Staph. aureus in the worker's clothes $/ \mathrm{m} 2$ were $2.8 \times 10,1.2 \times 102$, $2.6 \times 10,1.8 \times 10$, and $3.4 \times 102$, respectively. On the other hand, the mean TBC, TCC, TFCC, T. E. coli count, and T. Staph. aureus of the knives swabs $/ \mathrm{m} 2$ were $3.3 \times 102,3.1 \times 10,1.3 \times 10,1.0 \times 10$, and $3.2 \times 102$, respectively. The obtained results indicated that the contact surfaces may play a vital role in the contamination of meat during processing (Mead, 1989; and Schlegelova et al., 2010).

The interactions between the microbial populations in the environment and those on the surface of raw meat were represented in Table 2. So, our result demonstrated that there are positive correlations between TBC in environmental samples and those on the raw meat surfaces. In addition, positive correlations were found between swabs taken from knives used in beef cutlets and beef surface in terms of TBC, TCC, Total thermotolerant $E$. coli count, and total Staph. aureus count (Table 2). Moreover, a positive correlation was found between worker's clothing and meat surfaces in terms of total Staph. aureus counts.

Table 2. Pearson's correlation coefficients [r] for total bacterial, coliforms, fecal coliforms, $E$. coli, and staph. aureus counts for samples collected from raw meat surface versus environmental samples in the restaurant of Sohag University Hospital.

\begin{tabular}{lccccc}
\hline $\begin{array}{l}\text { Meat surface versus } \\
\text { Environmental sample }\end{array}$ & TBC & TCC & TFCC (MPN) & $\begin{array}{c}\text { Total E. coli. count } \\
\text { (MPN) }\end{array}$ & $\begin{array}{c}\text { Total Staph. } \\
\text { Aureus count }\end{array}$ \\
\hline Air & $0.86^{* *}$ & 0.27 & 0.38 & 0.05 & 0.33 \\
Water & $0.79^{*}$ & -0.08 & 0.46 & 0.08 & 0.31 \\
\hline Worker's hands & $0.69^{*}$ & 0.34 & 0.33 & 0.07 & 0.47 \\
Worker's clothes & $0.98^{* *}$ & 0.35 & 0.34 & 0.31 & $0.72^{*}$ \\
Knives' swab & $0.84^{* *}$ & $0.74^{*}$ & -0.02 & $0.62 *$ & $075^{*}$ \\
\hline
\end{tabular}

TBC; total bacterial count, TCC; total coliform count, TFCC; total fecal coliform count, total E. coli. count; MPN; most probable number, CFU; colony forming unit. Each value represents Pearson's correlation $[\mathrm{r}]<0.7$, strong correlation, $[\mathrm{r}]=0.5-0.7$, moderately to strong correlation, and $[\mathrm{r}]=0.3-$ 0.5 , weak to moderate correlation. * is significant if $P<0.05$, while $* *$ is significant if $P<0.01$.

Concerning the bacterial isolates, (Fig. 1) revealed 9 isolates. No Salmonella spp could be isolated from the meat surfaces, air, and tap water. The percentages of isolates were greatly different. Staph. epidermidis represent the main bacterial isolated from the meat surfaces, air, and tap water followed by staph. aureus. The enteropathogenic bacteria that could be isolated from the meat surfaces were $E$. coli (13.8\%); Pseudomonas aeroginosa (10.3\%); Klebsiella species (6.9\%); Proteus species $(6.9 \%)$ and Citrobacter species $(3.4 \%)$. This could be attributed to the contamination of beef during processing and handling of meat during processing and storage (Doxon et al., 1991; and Bartram et al., 2003). On the other hand, bacterial isolates of the contact surfaces of the knives, handler's hands, and clothes, Fig. 1. showed that the most prominent isolates were Staph. epidermidis and staph aureus in all examined samples followed by other enteropathogenic organisms such as E. coli, Pseudomonas aeroginosa, Enterobacter species, Proteus species, and Serratia species. No Salmonella or E. coli could be isolated from these samples except in handler's clothes (Schlundt, 2002; and Othman, 2015).

Microorganisms that are implicated in foodborne diseases may contaminate meat 
directly and indirectly especially from animal manure in slaughterhouses (Heredia and García, 2018). In addition, they can be transmitted to meat from the contact surfaces, utensils, and other slaughtering equipment (Yen, 2003; and Diyantoro and Wardhana, 2019). Contamination of meat surfaces constitutes a major problem in most developing countries' meat processing plants where they are considered potential sources of infection. In fact, microbial contaminations of carcasses have been repeatedly reported to play a significant role in the meat shelf life of beef (Khalafalla et al., 2016). Therefore, when all meatprocessing steps are carried out within a facility specifically prepared for meat processing, sources of contamination should be much more simply and sufficiently controlled. In most developing countries, the traditional methods of meat manipulation, processing, and presentation are the main cause of poor sanitation, which in turn leads to considerable loss of product as well as the risk of food-borne disease (Garcia, 2007; and Schmidt, 2019). Hence, fecal matter per se is a major source of contamination and could reach carcasses through direct contamination as well as indirectly by other vehicles and equipment as knives, worker's clothes, and hands (Abdalla et al., 2009). Furthermore, contaminations with pathogens such as Salmonella, E. coli, and other enteric bacteria that can reach the meat may cause severe health problems for the public (Kibret and Abera, 2012). Environmental contaminations with pathogenic bacteria remain to have a major concern for contaminating raw meat in developing countries. Raising the meat handlers' health awareness about spreading foodborne diseases in food processing plants is important in limiting outbreaks of these diseases (Adesokan and Raji, 2014).

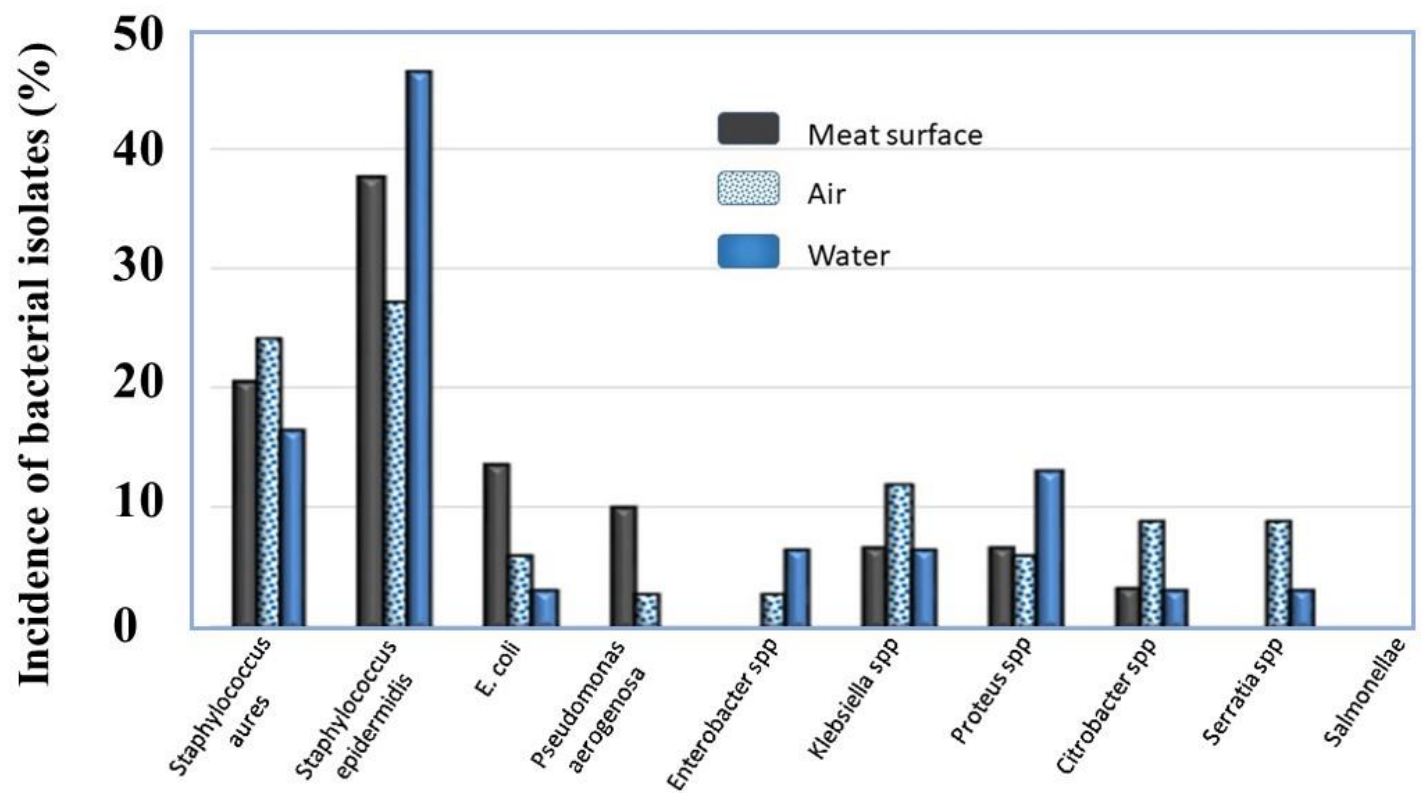

Figure 1. Incidence of bacterial isolates (\%) from raw meat surface, air, and water in the restaurant of Sohag University Hospital.

\section{Conclusion}

In conclusion, contamination of air and water, and unclean surfaces of tools equipment may be a potential source of microbial continuation of meat surface. Therefore, it is worthy to enhance the health awareness of personnel in food-processing plants about sanitary and hygienic measures and control practices that prevent microbial infections. 


\section{Acknowledgements}

The author thanks Sohag University Hospital Staff for their kind help in samples collections.

\section{Conflicts of interest}

All authors disclose the absence of any type of interest conflicts.

\section{Financial disclosures}

All authors disclose that they did not receive any funds for this study.

\section{References}

Abdalla MA, Suliman SE, Ahmed DE, Bakhiet AO (2009). Estimation of bacterial contamination of indigenous bovine carcasses in Khartoum (Sudan). African Journal of Microbiological Research, 3(12): 882-886.

Adesokan HK, Raji AO (2014). Safe meathandling knowledge, attitudes and practices of private and government meat processing plants' workers: implications for future policy. Journal of Preventive Medicine and Hygiene, 55(1): 10-16.

Almeida RC, Kuaye AY, Serrano AM, Almeida PF (1995). Evaluation and control of the microbiological quality of hands in food handlers. Rev. Saude Publica, 29: 290-294.

Amisu KO, Coker AO, On SL, Isokpehi RD (2003). Arcobacter butzlieri strains from poultry abattoir effluent in Nigeria. East Africa Medical Journal, 80: 218-221.

AOAC Official Methods of Analysis (2019). AOAC Official Methods of Analysis. $21^{\text {st }}$ Edition, Association of Official Analytical Chemists, Arlington.
American Public Health Association (APHA) (1998). Standard Methods for the Examination of Water and Wastewater, 20th ed. APHA, Washington, DC.

American Public Health Association (APHA) (2005). Standard methods for examination of water and waste water" 21th ed., APHA, Inc. Washington, DC.

Bartram J, Cotruvo M, Exner C, Fricker A, Glasmacher (2003). Heterotrophic Plate Counts and Drinking-water Safety: The Significance of HPCs for Water Quality and Human Health. TJ International (Ltd), Padstow, Cornwall, UK.

Bintsis T (2017). Foodborne pathogens. AIMS Microbiology, 3(3): 529-563.

Boadi KO, Kuitunen M (2003). Municipal solid waste management in the Accra metropolitan area, Ghana. The Environmentalist, 23:211-218.

Bridges O, Bridges JW, Potter JF (2000). A generic comparison of the airborne risks to human health from landfill and incinerator disposal of municipal solid waste. The Environmentalist, 20:325334.

Caplenas NR, Kanarek MS (1984). Thermotolerant non-fecal source Klebsiella pneumoniae: validity of the fecal coliform test in recreational waters. American Journal of Public Health, 74: 1273-1275

CDC. Center for disease control (2019). Guidelines for Environmental Infection Control in Health-Care Facilities. Accessible version: https://www.cdc.gov/infectioncontrol/g uidelines/environmental/index.html

Chan EF, Mowad C (1998). Contact Dermatitis to Food and Spices. 
American Journal of Contact

Dermatitis, 9: 71-79

Cruickshank R, Duguid JP, Marion BP, Swain RH (1980). Medical Microbiology" E.L.B.S., 12 ${ }^{\text {th }}$ Ed., Vol. II, reprinted Churchill Livingstone and Robert Stevenson. Edinburgh, EHI, 3 AF.

da Silva N, Taniwaki MH, Junqueira NF, do Nascimento MS, Gomes RA (2013). Microbiological examination methods of food and water. A laboratory manual. London, United Kingdom: CRC Press.

Diyantoro, Wardhana DK (2019). Risk Factors for Bacterial Contamination of Bovine Meat during Slaughter in Ten Indonesian Abattoirs. Veterinary Medicine International, 19: 2707064. 16.

Doxon DR, Acuff GR, Lucia LM, VanDerZandt C, Morgan JB, May SG, Savel JW (1991). Effect of degree of sanitation from slaughter through fabrication and sensory characteristics of beef. Journal of Food Protection, 4(3): 200-208.

Eijkman C (1904). The cooking test at $46^{\circ}$ as an aid in the investigation of drinking water. Central Bacteriology and Parasites Deptartment I. Orig. (in German) 37:742.

Egyptian Organization for Standardization and Quality (2005). Egyptian Standard, ES.https://www.eos.org.eg/en/standard $\mathrm{S}$

Feng P (1995). Escherichia coli serotype O157:H7: Novel vehicles of infection and emergence phenotypic variants. Emerging Infectious Diseases, 1: 16-21.

Fernandez MO, Thomas RJ, Garton NJ, Hudson A, Haddrell A, Reid JP (2019).
Assessing the airborne survival of bacteria in populations of aerosol droplets with a novel technology. Journal of the Royal Society Interface, 16: 20180779. http://dx.doi.org/10.1098/rsif.2018.077 9: $1-11$.

Ferragut V, Hernández-Herrero M, VecianaNogués MT, Borras-Suarez M, González-Linares J, Vidal-Carou MC, Guamis B (2015). Ultra-high-pressure homogenization (UHPH) system for producing high-quality vegetable-based beverages: physicochemical, microbiological, nutritional and toxicological characteristics. Journal of Science Food Agriculture, 95(5): 953961.

Fliss I, Simard RE, Ettriki AC (1991). Comparison of the three sampling techniques for microbiological analysis of meat surface. Journal of Food Science, 56(1): 249-250.

Garcia I (2007). Microscopic examination of natural sepsis bacterial populations from alpine streams. Canadian Journal of Microbiology, 3(3): 170-184.

Gauri, SM (2004). Characterization of effluent wastewater from abattoirs for land applications. Food Reviews International, 20(3): 229-256.

Heredia N, García S (2018). Animals as sources of food-borne pathogens: A review. Animal Nutrition, 4(3): 250255.

Khalafalla FA, Ali FHM, Hassan AHA, ElFeky KA (2016). Monitoring the bacterial contamination during different stages of beef carcass preparation at Beni-Suef abattoir, Egypt. Benha Veterinary Medical Journal, 30(1): 5158. 
Kibret M, Abera B (2012). The sanitary conditions of food service establishments and food safety knowledge and practices of food handlers in bahir dar town. Ethiopian Journal of Health Science, 22(1): 27 35 .

Kornacki JL (2014). An environmental sampling approach to product risk assessment. Food

Safety

Magazine, 20(1): 14-19.

Lee J, Fung D (1986). Methods for Sampling Meat Surfaces. Journal of Environmental Health, 48(4), 200-205.

Levin C, Warshaw E (2008). Protein Contact Dermatitis, Allergens, Pathogenesis and Management. Journal of America Contact Dermatitis, 19(5): 241-251.

Lou M, Liu S, Gu C, Hu H, Tang Z, Zhang Y, Xu C, Li F. (2021). The bioaerosols emitted from toilet and wastewater treatment plant: a literature review. Environmental Science Pollution Research International, 28(3): 25092521.

McLaughlin A, Mineau P (1995). The impact of agricultural practices on biodiversity. Agric. Ecosystem Environ. 55: 201-212.

Mead GC (1989). Hygiene problems and control of process contamination. In: Processing of Poultry. G.C. Mead (Ed.). Elsevier Applied Science, London, pp 183-220.

Meadows R (1995). Livestock legacy: Environmental Health Perspective, 103(12): 1096-1100.

Milios KT, Drosinos EH, Zoiopoulos PE (2014). Food Safety Management System validation and verification in meat industry: Carcass sampling methods for microbiological hygiene criteria- A review. Food Control, 43:7481.

Neufeld N (1984). Procedures for the bacteriological examination of seawater and shellfish. In: Greenberg, A.E. and D.A. Hunt (eds). 1984. Laboratory Procedures for the Examination of Seawater and Shellfish, 5th ed. American Public Health Association. Washington, DC.

Othman AS (2015). Isolation and microbiological identification of bacterial contaminants in food and household surfaces: How to deal safely. Egyptian Pharmaceutical Journal, 14(1): 1687-1691.

Oliveira M, Tiwari BK, Duffy G (2020). Emerging Technologies for Aerial Decontamination of Food Storage Environments to Eliminate Microbial Cross-Contamination. Foods, 30; 9 (12):1779.

Paul GE, Janet DE (2008). Laboratory Diagnosis of infectious Diseases Essentials of Diagnostic Microbiology Handbook Ed. By Williams \& Wilkins. 228-229.

Raheem NK, Morenikeji OA (2008). Impact of abattoir effluents on surface waters of the Alamuyo stream in Ibadan. Journal of Applied Science and Environmental Management, 12(1): 73-77.

Rawat S (2015). Food Spoilage: Microorganisms and their prevention. Asian Journal of Plant Science and Research, 5(4): 47-56.

Santl-Temkiv T, Amato P, Gosewinkel U, Thyrhaug R, Charton A, Chicot B, Finster K, Bratbak G, Löndahl J (2017). High-Flow-Rate Impinger for the Study 
of Concentration, Viability, Metabolic Activity, and Ice-Nucleation Activity of Airborne Bacteria. Environmental Science Technology, 3;51 (19):1122411234.

Schlundt J (2002). New directions in foodborne disease prevention. International Journal of Food Microbiology, 78: 3-17.

Sinha RK (1997). Fluorosis - A case study from the Sambher Salt Lake Region in Jaipur, Rajasthan, India. The Environmentalist, 17: 259-262.

Schlegelova J, Babak V, Holasova ML, Konstantinova (2010). Microbial Contamination after Sanitation of Food Contact Surfaces in Dairy and Meat Processing Plants. Czech Journal of Food Sciences, 28(5): 450-446.

Schmidt RH (2019). Food Science and Human Nutrition/Commercial Food Safety; Basic Elements of Equipment Cleaning and Sanitizing in Food Processing and Handling Operations. IFAS extension, UF, USA. 1-11.

Smith TA (2000). Occupational Skin Conditions in the Food Industry Occupational Medicine Vol 50 P597598 Oxford Journals.

Vuia-Riser J, Hieke AS, Athrey G, Kerth CR, Taylor TM (2018). Comparison of buffered peptone water to neutralizing buffered peptone water for Salmonella detection from commercially slaughtered whole chicken carcasses and cut chicken parts. Food Protection Trends, 38, (6): 410-420.

World Health Organization (WHO) (2006). Guidelines for Drinking Water-Quality" First Addendum to Third Edition. WHO Library Cataloguing-in-Publication Data

World Health Organization (WHO) (2010). Isolation of Salmonella spp. from food and animal faeces" WHO Global foodborne infections Network, $5^{\text {th }}$ Ed. June, 2010.

World Health Organization (WHO) (2015). WHO's first ever global estimates of foodborne diseases find children under 5 account for almost one third of deaths. https://www.who.int/news/item/03-122015.

World Health Organization (WHO) (2020). food safety https://www.who.int/newsroom/fact-sheets/detail/food-safety.

William RS (2000). Bergey's manual of determinative bacteriology (9th ed.). Philadelphia, USA: Lippincott Williams and Wilkins.

Yen KM (2003). Biofilms in food processing. Food Control, 6: 9-18. 